\title{
Isolation and development of microsatellite markers for the Brazilian Cerrado endemic tree frog Ololygon centralis (Anura: Hylidae)
}

\author{
A.A. Castro ${ }^{1}$, C.P. Targueta $^{1}$, V. Guerra ${ }^{2}$, P.G. Gambale ${ }^{3}$ and \\ M.P.C. Telles ${ }^{1,4}$ \\ ${ }^{1}$ Laboratório de Genética \& Biodiversidade, Departamento de Genética, \\ Instituto de Ciências Biológicas, Universidade Federal de Goiás, Goiânia, \\ GO, Brasil \\ ${ }^{2}$ Programa de Pós-graduação em Ecologia e Manejo de Recursos Naturais, \\ Universidade Federal do Acre, Rio Branco, AC, Brasil \\ ${ }^{3}$ Universidade Estadual de Mato Grosso do Sul, AC Dourados, Jardim \\ América, Dourados, MS, Brasil \\ ${ }^{4}$ Escola de Ciências Agrárias e Biológicas, Pontifícia Universidade Católica \\ de Goiás, Goiânia, GO, Brasil
}

Corresponding author: M.P.C. Telles

E-mail: tellesmpc@gmail.com

Genet. Mol. Res. 19 (1): gmr18528

Received November 29, 2019

Accepted February 21, 2020

Published March 31, 2020

DOI http://dx.doi.org/10.4238/gmr18528

\begin{abstract}
The aim of this study was to develop microsatellite markers for Ololygon centralis, an endemic tree frog species of the Cerrado biome of Brazil, to improve population genetics studies with focus on conservation and ecology. Sets of primers were designed from sequences derived from high throughput sequencing (IlluminaMiseq). Five polymorphic microsatellite loci were characterized for 30 individuals from three populations of the state of Goiás, Brazil. All loci combined presented a probability of identity (I) equal to $1.13 \times 10^{-6}$ and paternity exclusion $(\mathrm{Q})$ of 0.993 . The number of alleles per locus ranged from 5 to 17 , with a mean of 10 alleles. The expected and observed heterozygosity ranged from 0.41 to 0.98 and from 0 to 1 , respectively. The global fixation index $F_{\text {st }}$ found was $0.213(\mathrm{P}<0.05)$. These markers will be useful for genetic diversity
\end{abstract}


analysis and will contribute to population genetics studies for species of the Scinax (=Ololygon) catharinae clade.

Key words: Hylidae; Illumina; Molecular marker; SSR

\section{INTRODUCTION}

The Cerrado Biome includes a great biological richness, which makes it one of the biodiversity hotspots of the world (Ratter et al., 1997; Myers et al., 2000; Diniz-Filho et al., 2006). For anuran species, more than half of the known species found in the Cerrado are considered endemic (Valdujo et al., 2012). However, several factors are contributing to a decrease in the number of amphibian species, such as: habitat fragmentation, habitat loss, global warming and diseases (Stuart et al., 2004). Furthermore, human occupation and habitat fragmentation can also cause loss of genetic diversity in amphibian populations (Telles et al., 2007). Although still relatively little studied, knowledge about anuran genetic diversity is important for planning biodiversity conservation in this group (Faggioni et al., 2014).

Genetic information concerning anuran populations has been acquired by the use of microsatellite markers (Jehle and Arntzen, 2002; Fabres et al., 2018; Wooten et al., 2018). The development of markers associated with high-throughput sequencing (HTS) approaches have increased the comprehension of genetic variability in population studies, since it makes access to genomes of non-model organisms feasible (Ekblom and Galindo, 2011). Recently, this approach made viable the development of microsatellite markers for various anuran species, for example: Nanorana parkeri with 113 new microsatellite markers (Wang et al., 2013), Leptodactylus bufonius with 17 markers, Leptodactylus chaquensi with 16 markers (Faggioni et al., 2014), Bokermannohyla sp. with 22 markers (Nali et al., 2014), Quasipaa boulengeri with 32 markers (Yuan et al., 2015), Telmatobius chusmisensis with 22 markers (Fabres et al., 2018), and Bufotes viridis with 12 markers (Vences et al., 2019).

Few studies have developed and used microsatellite markers for amphibians of the Cerrado biome (e.g. Telles et al., 2007; Conte et al., 2009; Arruda et al., 2012; Nali et al., 2014). Ololygon centralis (=Scinax centralis) is a Cerrado endemic tree frog and genetic information is restricted to its karyotype (Targueta et al., 2018). This small hylid species presents an interocular spot in the form of an inverted triangle, and an inguinal region with yellow dots where it is possible to find a well-developed gland in males (Pombal and Bastos, 1996; Brito et al., 2019). Males are territorial and are mostly found vocalizing on leaves near a water source (Alcantara et al., 2007). The species inhabits gallery forests, with vegetation that is similar to that found in the Atlantic Forest, the biome that has greatest diversity of species of the genus Ololygon (Moura et al., 2010). According to the International Union for Conservation of Nature (IUCN) Red List (https://www.iucnredlist.org/), O. centralis is classified as "Least Concerned" because of its distribution inside protected areas. However, population sizes are shrinking due to anthropogenic activities, such as agriculture, cattle ranching and arson, which are also threats for other amphibian species (Stuart et al., 2004; Ribeiro et al., 2017).

Since microsatellite markers can contribute to studies about the genetic diversity of natural populations of anurans, the aim of this study was to develop a set of polymorphic 
microsatellite markers for $O$. centralis. Further, the markers were tested in Scinax constrictus, a closely related species also endemic to the Brazilian Cerrado.

\section{MATERIAL AND METHODS}

Genomic DNA was extracted from liver tissue of 30 specimens of $O$. centralis collected in three municipalities of the state of Goiás: Caldas Novas (7 specimens), Pires do Rio (7 specimens) and Silvânia (16 specimens), being the last the type-locality (Supplementary 1). The individuals were collected between December 2014 and May 2015 under authorization of the Animal Use Ethics Committee of the Universidade Federal de Goiás (UFG), number 109/14. The specimens were found perched on vegetation near water bodies by visual and acoustic search. All sampled sites were gallery forests with relatively well preserved native vegetation, but were surrounded by a matrix of pastures. The animals were anesthetized with $2 \%$ xylocaine for tissue removal and were subsequently fixed in $10 \%$ formaldehyde and stored in $70 \%$ alcohol. All specimens were deposited at the Zoological Collection of the UFG. The data reported herein is from the Master's thesis of the first author (Castro, 2018).

For DNA extraction, tissues were submitted to mechanical fragmentation in lysis buffer containing $50 \mathrm{mM}$ Tris-HCl, pH 8.0; $25 \mathrm{mM}$ EDTA and $400 \mathrm{mM} \mathrm{NaCl}$. The samples were added with SDS $20 \%$ and Proteinase $\mathrm{K}(10 \mathrm{mg} / \mu \mathrm{L})$. The samples were incubated at $56^{\circ} \mathrm{C}$ for approximately $5 \mathrm{~h}$ for the enzymatic digestion. After this time, $\mathrm{NaCl} 5 \mathrm{M}$ was added to the samples followed by a centrifugation step. Sodium acetate $3 \mathrm{M}$ were added to the supernatant and DNA precipitation were performed adding ethanol. The pellet was resuspended in TE $(\mathrm{pH} 8.0)+$ RNAse $(10 \mathrm{mg} / \mu \mathrm{L})$. The DNA quality was analyzed by horizontal electrophoresis in agarose gel $1 \%$.

The genomic library was constructed from the DNA of two samples (OCE-FLO3 and OCE-FLO5) from the type-locality, Floresta Nacional de Silvânia - FLONA, state of Goiás, Brazil. The DNA quantification was performed in Qubit ${ }^{\circledR}$ fluorometer 2.0 using Qubit dsDNA HS Assay (Thermo Fisher Scientific). For library preparation, we used $50 \mathrm{ng}$ of DNA from each sample following the protocol of Nextera DNA Library Prep kit (Illumina). The libraries were validated through Agilent Technologies 2100 Bioanalyzer using the High Sensitivity DNA kit (Agilent) and quantified by real time PCR using Kapa Library Quantification kit (Biosystems; KK4824). The sequences were generated in two rounds in Miseq Illumina platform using Miseq v3 600 cycles kit (Illumina). The resulted reads were assembled in dipSpades 1.0 (Safonova et al., 2015).

For the identification of microsatellite regions, we used the software QDD version 3.1.2 (Meglécz et al., 2009; Meglécz et al., 2014). The software also designed primers for microsatellite isolation followed by the parameters: PCR product ranging from 150 to 400 $\mathrm{bp}$, annealing temperature between $56-62^{\circ} \mathrm{C}$, primer size $22-25$ bp and GC content of 30$60 \%$. We selected 31 pairs of primers for PCR optimization. The amplified products were visualized in agarose gel 3\% and polyacrylamide gel $6 \%$ for a better resolution of fragment sizes. A set of forward primers, referred to microsatellite regions, were synthetized with a fluorophore at it 5'end using the matrix DS33 (6'FAM, NED and VIC).

The amplification reactions were performed as followed: $6 \mu \mathrm{L}$ of DNA $(2.5 \mathrm{ng} / \mu \mathrm{L})$, $1.0 \mu \mathrm{L}$ of each primer forward and reverse $(0.9 \mu \mathrm{M}), 1.5 \mu \mathrm{L} 10 \mathrm{X}$ buffer $(500 \mathrm{mM} \mathrm{KCl} ; 100$ $\mathrm{mM}$ Tris- $\mathrm{HCl} \mathrm{pH} 8.4 ; 1 \%$ Triton X-100), $1.2 \mu \mathrm{L}$ of $\mathrm{MgCl}_{2}(50 \mathrm{mM}), 1.5 \mu \mathrm{L}$ of dNTP $(2.5$ 
$\mu \mathrm{M}), 0.2 \mu \mathrm{L}$ of Taq DNA polymerase Phoneutria (5 U) and ultrapure water for a final volume of $15 \mu \mathrm{L}$. The amplification cycles contained the following steps: (1) Initial denaturation at $96^{\circ} \mathrm{C} / 5 \mathrm{~min}$.; (2) 35 cycles with $96^{\circ} \mathrm{C} / 1 \mathrm{~min}$., specific annealing temperature for each primer/ $1 \mathrm{~min}$. (Table 2), $72^{\circ} \mathrm{C} / 1 \mathrm{~min}$.; (3) final extension of $72^{\circ} \mathrm{C} / 45 \mathrm{~min}$.

The obtained fragments were genotyped through Genetic analyzer ABI3500 (Applied Biosystems ${ }^{\circledR}$ ) using the size standard GeneScan 600 LIZ $^{\mathrm{TM}}$ (Life Technologies ${ }^{\circledR}$ ). The data was verified in software GeneMapper v. 5.0 (Applied Biosystems ${ }^{\circledR}$ ). The presence of null alleles, stutter and dropout were checked using MICRO-CHECKER (Van Oosterhout et al., 2004).

We also tested the transferability of markers to three samples of a close related species S. constrictus (ZUFG8718; ZUFG8728 and ZUFG10386) according the protocols described above. All pairs of primers designed for microsatellite region in $O$. centralis were used for transferability in S. constrictus.

For microsatellite markers, we estimated: the allelic and genotypic frequencies, the mean number of alleles per locus (A); expected heterozygosity (He), observed heterozygosity (Ho), fixation index $\left(\mathrm{F}_{\mathrm{IS}}\right)$ and populational genetic differentiation index $\left(\mathrm{F}_{\mathrm{ST}}\right)$ using software FSTAT 2.9.3.2 (Goudet, 2002). The probability of paternity exclusion (Q) and the probability of genetic identity (I) were calculated by IDENTITY 1.0 (Wagner and Sefc, 1999). For the analysis of linkage disequilibrium we used the software GDA (Lewis and Zaykin, 2002).

\section{RESULTS AND DISCUSSION}

The assembled contigs resulted in $4.9 \mathrm{Mbp}$ of genome data for $O$. centralis. It was possible to identify 256 microsatellite regions in the assembled contigs. Eighty-seven pairs of primers were design for those regions. From those, forty-seven were designed for regions containing tetranucleotides, thirty-nine for dinucleotide loci and one for trinucleotide region. Thirty-one pairs of primers were selected, from which, eighteen were successfully used for amplification and had their annealing temperature standardized. Among them, eleven loci were monomorphic and seven showed polymorphisms. Five polymorphic loci were established as new set of microsatellite markers and used for genotype individuals of O. centralis. The annealing temperature for each of those five markers is shown in Table 1 .

Table 1. Characterization of five microsatellite markers isolated for Ololygon centralis and analyzed in 30 individuals of this species from Central Brazil.

\begin{tabular}{|c|c|c|c|c|c|c|c|c|c|c|}
\hline Locus & Primer Sequence (5'-3') & Labeling dye & Repeat Motif & $\mathbf{A T}\left({ }^{\circ} \mathbf{C}\right)$ & Size Range (bp) & AN & Ho & $\mathrm{He}$ & $\mathbf{I}$ & $\mathbf{Q}$ \\
\hline OCE05 & $\begin{array}{l}\text { F:TCATAGGTAGGCATATAGATGGA } \\
\text { R: ATATGCTGAGAACGCATTGTA }\end{array}$ & VIC & $(\mathrm{AGAT}) 9$ & $56^{\circ} \mathrm{C}$ & $218-256$ & 8 & 0.490 & 0.609 & 0.108 & 0.517 \\
\hline OCE11 & $\begin{array}{l}\text { F: AGGTTCCTAAGTATCAGATCCC } \\
\text { R: AGTTCTCCTTTAACCCTTTCAG }\end{array}$ & VIC & (AC) 10 & $54^{\circ} \mathrm{C}$ & $180-228$ & 12 & 0.448 & 0.780 & 0.075 & 0.592 \\
\hline OCE20 & $\begin{array}{l}\text { F:TCCATCTATCCATCTATATGTCACT } \\
\text { R: AAGATTTATTCACCCAATGTGA }\end{array}$ & NED & $(\mathrm{AGAT}) 10$ & $58^{\circ} \mathrm{C}$ & $148-164$ & 5 & 0.774 & 0.588 & 0.231 & 0.336 \\
\hline OCE21 & $\begin{array}{l}\text { F: AATCTGCGAGTTGTATATGAGC } \\
\text { R: ACTGCTTTCTTCATCTCTAGCA }\end{array}$ & VIC & $(\mathrm{AGAT}) 9$ & $54^{\circ} \mathrm{C}$ & $218-318$ & 17 & 0.505 & 0.872 & 0.013 & 0.829 \\
\hline OCE26 & $\begin{array}{l}\text { F: ATGAATGATTGTTTGCACAGTA } \\
\text { R: GCATCAAGAAAGACAACCTAAA }\end{array}$ & 6'FAM & $(\mathrm{AAAC}) 5$ & $56^{\circ} \mathrm{C}$ & $182-262$ & 8 & 0.394 & 0.642 & 0.046 & 0.678 \\
\hline Mean & - & - & - & - & - & 10 & 0.522 & 0.698 & $1.13 \times 10^{-6}$ & 0.993 \\
\hline
\end{tabular}

AT: Annealing temperature, AN: number of alleles, Ho: observed heterozygosity, He: expected heterozygosity, I: Probability of identity, Q: exclusion of paternity. 
The microsatellite markers showed a combined probability of identity (I) of $1.13 \times 10^{-6}$, which indicates that the loci may be useful to discriminate between individuals of O. centralis. In addition, paternity exclusion (Q) was 0.993 , which represents high probability of exclude false paternity (Table 1). For linkage disequilibrium, no significative value was detected for the three populations analyzed.

Considering the three populations of $O$. centralis, the number of alleles changed from 5 to 17 , the mean expected heterozygosity between the 5 loci were 0.69 , ranging from 0.41 to 0.98 . The mean observed heterozygosity was 0.522 ranging from 0 to 1 (Table 2). For locus OCE20, it was possible to find an excess of heterozygotes in the three populations. The locus OCE05 for the population from Silvânia and the locus OCE21 for the population of Pires do Rio showed a deviation from the Hardy-Weinberg equilibrium, showing significative $\mathrm{F}_{\mathrm{IS}}$. This could be explained by the possibility of endogamy in these populations and, also, the presence of null alleles found for those loci (OCE05-Silvânia = 0.3343 and OCE21-Pires do Rio $=0.4001$ ).

Table 2. Genetic parameters for the five microsatellite loci analyzed for three populations of Ololygon centralis in Central Brazil.

\begin{tabular}{|c|c|c|c|c|c|c|c|c|c|c|c|c|}
\hline \multirow[b]{2}{*}{ Locus } & \multicolumn{4}{|c|}{$\begin{array}{l}\text { Pop. Silvânia } \\
(n=16)\end{array}$} & \multicolumn{4}{|c|}{$\begin{array}{l}\text { Pop. Caldas Novas } \\
(n=7)\end{array}$} & \multicolumn{4}{|c|}{$\begin{array}{l}\text { Pop. Pires do Rio } \\
(n=7)\end{array}$} \\
\hline & NA & Ho & He & $\mathbf{F}_{\text {IS }}$ & NA & Ho & $\mathrm{He}$ & $\mathbf{F}_{\text {IS }}$ & NA & Ho & He & $\mathbf{F}_{\text {IS }}$ \\
\hline OCE05 & 3 & 0.06 & 0.41 & $0.85^{*}$ & 5 & 0.86 & 0.85 & -0.01 & 4 & 0.71 & 0.57 & -0.25 \\
\hline OCE11 & 5 & 0.25 & 0.59 & 0.58 & 5 & 0.43 & 0.86 & 0.50 & 7 & 0.71 & 0.89 & 0.20 \\
\hline OCE20 & 4 & 0.63 & 0.53 & -0.19 & 3 & 0.71 & 0.52 & -0.36 & 4 & 1.00 & 0.71 & -0.40 \\
\hline OCE21 & 7 & 0.88 & 0.82 & -0.07 & 6 & 0.43 & 0.82 & 0.48 & 7 & 0.14 & 0.98 & $0.85^{*}$ \\
\hline OCE26 & 4 & 0.50 & 0.64 & 0.23 & 2 & 0 & 0.48 & 1.00 & 5 & 0.86 & 0.80 & -0.08 \\
\hline Mean/Global & 4.6 & 0.46 & 0.60 & 0.28 & 4.2 & 0.49 & 0.70 & 0.32 & 5.4 & 0.68 & 0.79 & 0.06 \\
\hline
\end{tabular}

(Pop.) population, (n) numbers of individuals sampled, (NA) allele numbers, (Ho) observed heterozygosity, (He) expected heterozygosity, $\left(\mathrm{F}_{\mathrm{IS}}\right)$ fixation index. *Significant for Hardy-Weinberg equilibrium $(\mathrm{P}<0.05)$.

The global value of $\mathrm{F}_{\mathrm{ST}}$ was $0.213(\mathrm{P}<0.05)$, which indicates a high level of genetic differentiation since $20 \%$ of genetic variation are presented in the component of populations. Pairwise $\mathrm{F}_{\mathrm{ST}}$ was also significant, between them the higher value was found between the populations of Silvânia and Pires do Rio $\left(\mathrm{F}_{\mathrm{ST}}=0.232 ; \mathrm{P}<0.05\right)$, followed by Silvânia and Caldas Novas $\left(\mathrm{F}_{\mathrm{ST}}=0.227 ; \mathrm{P}<0.05\right)$, and Caldas Novas and Pires do Rio $\left(\mathrm{F}_{\mathrm{ST}}\right.$ $=0.144 ; \mathrm{P}<0.05)$.

Despite the results found for microsatellite markers in $O$. centralis, we did not have success with transferability to Scinax constrictus. We changed the annealing temperature between 50 and $60^{\circ} \mathrm{C}$, and the magnesium chloride concentration from 25 to $50 \mathrm{mM}$ for each PCR reaction but did not succeed. Both species occur in the Cerrado Biome and are included in the same subfamily Scinaxinae, although they are not direct phylogenetic relatives (Duellman et al., 2016). Therefore, the phylogenetic distance among them could explain the unsuccessful amplification of markers.

\section{CONCLUSIONS}

In conclusion, we developed useful microsatellite markers for $O$. centralis using sequence data obtained from HTS sequencing. We characterized five polymorphic regions 
that can be now applied for population genetic studies in this anuran species. Although we did not acquire success in transferability to $S$. constrictus, these markers may be useful for species evolutionarily closer to $O$. centralis, especially those belonging to the Scinax (= Ololygon) catharinae clade.

\section{ACKNOWLEDGMENTS}

The work was developed with grants from Fundação de Amparo à Pesquisa do Estado de Goiás DOC-FIX-FAPEG 04/2014. Current research was also developed in the context of National Institutes for Science and Technology (INCT) in Ecology, Evolution and Biodiversity Conservation, supported by MCTIC/CNpq (proc. 465610/2014-5) and FAPEG. AAC e VG would like to thank the scholarship grant of Coordenação de Aperfeiçoamento de Pessoal de Nível Superior (CAPES), CPT was granted by scholarship from project DOC-FIX-FAPEG 04/2014. PRONEX CP No. 06/2016 (FAPEG/CNPq). M.P.C.T. have been continuously supported by productivity fellowships from 'Conselho Nacional de Desenvolvimento Científico e Tecnológico' (CNPq), which we gratefully acknowledge. We thank SISBio/ICMBio for collection permission (number 46522-3).

\section{CONFLICTS OF INTEREST}

The authors declare no conflict of interest.

\section{REFERENCES}

Alcantara MB, Lima LP and Bastos RP (2007). Breeding activity of Scinax centralis (Anura, Hylidae) in Central Brazil. Iheringia. Série Zoologia. 97: 406-410. https://dx.doi.org/10.1590/S0073-47212007000400008.

Arruda MP, Costa WP, Silva CC and Pimentel SMR (2012). Development of 22 polymorphic microsatellite loci for the critically endangered Morato's Digger Toad, Proceratophrys moratoi. Int. J. Mol. Sci. 13: 12259-12267.

Brito P, Targueta CP, Arruda W, Santos F, et al. (2019). The sexual dimorphic inguinal glands of the frog species Ololygon centralis (Anura: Hylidae) at light and transmission electron microscopy. Zoologia. 36. https://dx.doi.org/10.3897/zoologia.36.e29356.

Castro AA (2018). Desenvolvimento de marcadores microssatélites para Ololygon centralis (ANURA: HYLIDAE) por sequenciamento de segunda geração com baixa cobertura. Tese de Mestrado. Universidade Federal de Goiás, Goiânia. Available at [https://repositorio.bc.ufg.br/tede/handle/tede/8343].

Conte M, Cançado LJ, Laborda PR, Zucchi MI, et al. (2009). Isolation and characterization of polymorphic microsatellites for the natural populations of barker frog Physalaemus cuvieri. Conserv. Genet. 10: 1849-1852. doi: $10.1007 / \mathrm{s} 10592-009-9832-1$

Diniz-Filho JAF, Bini LM, Pinto MP, Rangel TFLVB, et al. (2006). Anuran species richness, complementarity and conservation conflicts in Brazilian Cerrado. Acta Oecologica. 29: 9-15. doi: 10.1016/j.actao.2005.07.004.

Duellman WE, Marion AB and Hedges SB (2016). Phylogenetics, classification, and biogeography of the treefrogs (Amphibia: Anura: Arboranae). Zootaxa. 4104: 1-109.

Ekblom R and Galindo J (2011). Applications of next generation sequencing in molecular ecology of non-model organisms. Heredity (Edinb). 107: 1.

Fabres A, Fibla P, Araya C, Sallaberry M, et al. (2018). Development and characterization of 22 polymorphic microsatellites of the Andean frog Telmatobius chusmisensis (Anura, Telmatobius) and cross amplification in seven Chilean species of the genus. Mol. Biol. Rep. 45: 1533-1538.

Faggioni GP, Zamudio KR, Souza FL and Prado CPA (2014). Isolation and characterization of microsatellites markers for two South American frogs (Leptodactylus bufonius and L. chaquensis) using next generation sequencing. Amphib Reptil. 35: 405-412. doi: 10.1163/15685381-00002961.

Goudet J (2002). FSTAT, A Program to Estimate and Test Gene Diversities and Fixation Indices, version 2.9. 3. Available at [https://www2.unil.ch/popgen/softwares/fstat.htm].

Jehle R and Arntzen JW (2002). Microsatellite markers in amphibian conservation genetics. Herpetol. J. 12: 1-9.

Lewis PO and Zaykin D (2002). GDA (Genetic Data Analysis). Softw. Distrib. by authors 
Meglécz E, Costedoat C, Dubut V, Gilles A, et al. (2009). QDD: A user-friendly program to select microsatellite markers and design primers from large sequencing projects. Bioinformatics. 26: 403-404. doi: 10.1093/bioinformatics/btp670.

Meglécz E, Pech N, Gilles A, Dubut V, et al. (2014). QDD version 3.1: a user-friendly computer program for microsatellite selection and primer design revisited: experimental validation of variables determining genotyping success rate. Mol. Ecol. Resour. 14: 1302-1313.

Moura MR de, Fernandes VD, Santana DJ and Feio RN (2010). Amphibia, Anura, Hylidae, Scinax centralis Pombal and Bastos, 1996: Distribution extension, geographic distribution map. Check List. 6: 173-175. doi: 10.15560/6.1.173.

Myers N, Mittermeier RA, Mittermeier CG, Da Fonseca GAB, et al. (2000). Biodiversity hotspots for conservation priorities. Nature. 403: 853.

Nali RC, Zamudio KR and Prado CPA (2014). Microsatellite markers for Bokermannohyla species (Anura, Hylidae) from the Brazilian Cerrado and Atlantic Forest domains. Amphib. Reptil. 35: 355-360. doi: 10.1163/1568538100002950 .

Pombal-Jr JP and Bastos RP (1996) Nova espécie de Scinax Wagler, 1830 do Brasil Central (Amphibia, Anura, Hylidae). Bol. Mus. Nac. Nova Ser. Zool. 371: 1-11.

Ratter JA, Ribeiro F, Agricultural B and Ribeiro F (1997).The Brazilian Cerrado Vegetation and Threats to its Biodiversity. Ann. Bot. 80: 223-230. doi: 10.1006/anbo.1997.0469.

Ribeiro J, Colli GR and Soares AM (2017). The anurofauna of a vanishing savanna: the case of the Brazilian Cerrado Biodiversity and Conservation. 1: 23. https://doi.org/10.1007/s10531-017-1468-8.

Safonova Y, Bankevich A and Pevzner PA (2015). dipSPAdes: assembler for highly polymorphic diploid genomes. $J$. Comput. Biol. 22: 528-545.

Stuart SN, Chanson JS, Cox NA, Young BE, et al. (2004). Status and trends of amphibian declines and extinctions worldwide. Science. 306: 1783-1786.

Targueta CP, Guerra V, Gambale PG, Bastos RP, et al. (2018). Cytogenetics of two hylid frogs from Brazilian Cerrado. Genet. Mol. Biol. 41: 814-819.

Telles MP de C, Diniz-Filho JAF, Bastos RP, Soares TN, et al. (2007). Landscape genetics of Physalaemus cuvieri in Brazilian Cerrado: Correspondence between population structure and patterns of human occupation and habitat loss. Biol. Conserv. 139: 37-46. doi: 10.1016/j.biocon.2007.06.003.

Valdujo PH, Silvano DL, Colli G and Martins M (2012). Anuran Species Composition and Distribution Patterns in Brazilian Cerrado, a Neotropical Hotspot. South Am. J. Herpetol. 7: 63-78. doi: 10.2994/057.007.0209.

Van Oosterhout C, Hutchinson WF, Wills DPM and Shipley P (2004). MICRO-CHECKER: Software for identifying and correcting genotyping errors in microsatellite data. Mol. Ecol. Notes. 4: 535-538. doi: 10.1111/j.14718286.2004.00684.x.

Vences M, Perl RG, Giesen K, Schluckebier R, et al. (2019). Development of new microsatellite markers for the Green Toad, Bufotes viridis, to assess population structure at its northwestern range boundary in Germany. Salamandra. 55: 191-198.

Wagner HW and Sefc KM (1999). IDENTITY 1.0. Cent. Appl. Genet. Univ. Agric. Sci. Vienna 500.

Wang C, Hu X, Xie X, Liu P, et al. (2013). Isolation and characterization of 113 polymorphic microsatellite loci for the Tibetan frog (Nanorana parkeri) using next generation sequencing. Conserv. Genet. Resour. 5: 915-924. doi: 10.1007/s12686-013-9932-6.

Wooten JA, Klooster MR, Brown AD, Bradford PR, et al. (2018). Characterization of Eight Microsatellite Markers for Use in Studies of Genetic Diversity and Hybridization in Bufo microscaphus and Bufo woodhousii (Anura: Bufonidae) in Arizona, USA. J. Arizona-Nevada Acad. Sci. 47: 45-53. doi: 10.1016/B978-0-12-374430-2.00030-4

Yuan S, Xia Y, Zheng Y and Zeng X (2015). Development of microsatellite markers for the spiny-bellied frog Quasipaa boulengeri (Anura: Dicroglossidae) through transcriptome sequencing. Conserv. Genet. Resour. 7: 229-231. 